\title{
INTERNATIONAL DIGITAL PLATFORM AS A TOOL FOR THE FORMATION OF CROSS-BORDER RESEARCH, EDUCATIONAL AND INNOVATION SPACES
}

Formulation of the problem. According to economic theory, there are four main types of economic growth: (1) Smithian economic growth (main factor is division of labor); (2) Malthusian economic growth (main factor is population); (3) Schumpeterian economic growth (main factor is innovations); (4) Northian economic growth (main factor is institutions). So the modern art of managing economic development at the state level is combination of this tools under certain conditions.

There are depopulation and decreasing of division of labour in Ukraine. It hinders Smithian and Malthusian economic growth. So Schumpeterian and Northian economic growth become relatively more important for state. Innovation is impossible without a highly developed educational and research spaces. Consequently, it's necessary to create conditionals for provide improvement of innovation, research and educational spaces in Ukraine to provide economic growth. The solving of this problem can be find in integration of these spaces in the space of EU.

At the same time, it is necessary to take into account the digitalization of the economy. Digital platforms can be a technical and organizational tool for such integration.

Literature review. Researchers of innovation, educational and research spaces consider various aspects: status of implementation of the Ukraine-European Union Association Agreement in the field of science, technology and innovation; European research area (ERA); EU Research and Innovation Framework Programs (Horizon Europe); Ukraine's participation in European programs and organizations; Roadmap for Ukraine's integration into the European Research Area and prospects for participation in joint EU initiatives; Directions for strengthening scientific, technological and innovative cooperation between Ukraine and the EU [1]; the concept of "Innovation Elevator: from school to Europe" as a tool for "growing" innovative startups in terms of integration into the European Research Area, taking into account migration processes; Network of regional research centers of NAS and MES of Ukraine as a basis for the formation of regional and cross-border innovation systems, high-tech clusters, interstate and cross-border research, educational and innovation spaces [2]; ERA funding and Ukraine's participation in European programs [3]; Priorities and goals of Ukraine's integration into the European Research Area, identified by ERA-UA, and its weaknesses [4].

As a result of these researches, such problems highlighted [1]:

- low level of strategic planning for the development of science, technology and innovation;

- the absence of the National Plan for the Implementation of the Roadmap for Ukraine's Integration into the ERA, approved by the Ministry of Education and Science of Ukraine in 2018;

- lack of coherence and coordination of policy in the field of science, education and innovation with other types of policies in industry, entrepreneurship, investment, social sphere, infrastructure in order to create a favorable business, regulatory and institutional environment to stimulate demand for innovation from industry, government, citizens, foreign partners, including from EU member states;

- inconsistency of actions of the authorities to implement the declared for decades plans for the development of innovative economy, which led to personnel and financial depletion of science, obsolescence of scientific infrastructure, almost complete lack of links between science and industry, low demand for innovation from business;

- limited access of Ukrainian researchers to European research infrastructures and electronic infrastructures, lack of the National Roadmap for research infrastructures.

When studying the problems of forming a single innovative, scientific and educational space Ukraine$\mathrm{EU}$, the possibility of using high technological and organizational tools (such as big digital platforms) remains outside the focus of attention of researchers. The potential of platform digitalization of innovation, research and educational spaces for their integration is not considered (not on national, not on multinational levels). This determined the choice of the research aim.

Aim of research. Based on a review of the literature and unsolved research problem, the aim of the study is to substantiate design international digital platform as a tool for the formation of cross-border research, educational and innovation spaces.

Presentation of the basic material. In the era of digital transformation, the main technological and organizational tools for the formation of interstate and cross-border research, educational and innovation 
spaces are related to the creation and dissemination of digital platforms, which became the basis of the platform revolution [5] and digitalization of the economy. Digital platforms are influencing the development of creative labour. They transform ordinary labour, leisure and everyday activities into creative labour [6]. The platform revolution has taken place in recent decades, as a result of which digital platforms have become an integral part of any activity, including research, education and innovation.

There are different types of digital platforms. For example, there are innovation, transactional, integration and investment platforms [7, p. 9]. «A transaction platform is a technology, product or service that acts as a conduit (or intermediary) facilitating exchange or transactions between different users, buyers, or suppliers. An innovation platform is a technology, product or service that serves as a foundation on top of which other firms (loosely organized into an innovative ecosystem) develop complementary technologies, products or services. An integrated platform is a technology, product or service that is both a transaction platform and an innovation platform. This category includes companies such as Apple, which has both matching platforms like the App Store and a large third-party developer ecosystem that supports content creation on the platform. Investment platforms consist of companies that have developed a platform portfolio strategy and act as a holding company, active platform investor or both» [7, p. 9].

Companies that use innovative platforms include Microsoft, Oracle, Intel, SAP and others. Companies that use transactional platform include Tensent, Paypal, Netflix, Ebay, Uber, Airbnb and others. Companies that use integration platform include Google, Apple, Alibaba, Amazon, Facebook and others. Companies that use investment platform include Softbank, Naspers, Priceline and others. [7, p.14]. Given the diverse activities of these companies, it becomes clear that the division into types is quite conditional, because the vast majority of technology companies use different types of platforms, or rather implement them within a single digital platform or several digital platforms operated by one company. Also, not only innovative digital platforms contribute to the creation of innovations and the formation of innovation space.

At the same time, crowdfunding digital platforms are increasingly expanding their activities to support innovative projects. For example, in North America, Europe and Asia, there are hundreds of crowdfunding platforms that attract tens of billions of dollars [8, p. 73]. Academic crowdfunding digital platforms are also being developed to support small academic innovations [9].

Apart from the digital platforms discussed above, there are educational and scientific digital platforms. The former provide access to online education (Coursera, Skillshare, Udemy, adX, etc.), the latter aggregate scientific information (RePEc, Scopus, etc.).

But the activities of innovative, scientific and educational digital platforms are not combined with the logic of a single innovation process, which includes a wide range of mutually agreed stages. Based on the analysis of the cycle of creation and dissemination of innovations $[10$, p. 20] there are 7 stages: (1) generation of scientific ideas as a result of research, (2) selection of ideas from the standpoint of organizational and technological opportunities and market prospects; (3) copyright protection; (4) development of a feasibility study; (5) creation of a new, innovative product, (6) organization of serial production; (7) the entry of innovative products into the market (commercialization of innovations). Further, the commercialized product goes through its life cycle within which the added value thickens, which creates an opportunity to launch a new innovation cycle. All stages are permeated by the educational space, which is the zero stage preceding stage (1). It also creates conditions for improving the implementation of other stages.

These digital platforms of each type play a positive role in the innovation process, but none of the platforms combines the first four stages. In fact, the scientific and educational spaces, which is the basis for the creation of innovative ideas and products, is mostly outside the activities of commercial innovative digital platforms. This problem can be solved through the implementation of an international digital platform for innovation, research and education space (hereinafter IDP «IRES»). The conceptual model of IDP «IRES» is presented in the Figure. Ukraine has opportunity to create big digital platform [11-12] and be a leader in this area.

The attributes of each digital platform on the basis of which the key interaction within the platform takes place are the participants, units of value and filter [13, p. 34-35]. For IDP «IRES», users are research organizations, businesses, educational organizations, governments, patent and consulting organizations. The units of value are money and information, which formalized in innovative ideas and accompanying documents. The filter is applied to registers of innovative ideas, products, research and educational organizations, investors and consulting companies.

The initiators of the IDP «IRES» deployment are the governments of the states. And its activities are administered by a specially created international organization.

Within the block «Generation of innovative ideas» is creating of innovative ideas. This process is carried out by research organizations that are authorized on the platform. Also there is the interaction of these organizations to develop new ideas on the platform.

Within the block «Selection of ideas» there is a prioritization and selection of ideas, which is done by representatives of business, research and consulting organizations together.

The protection of selected ideas from the standpoint of copyright takes place within the block «Copyright Protection». The performer of this work is selected through Dutch auctions among patent organizations, which the authorized on the platform. 
Consulting companies are involved in the development of the feasibility study through the «Feasibility study development» block, where also use the Dutch auction procedure. Based on the results of the activity, a register of innovative projects that have a feasibility study and protection of intellectual property right is formed.

The right to implement innovative projects is distributed among investors (or their consortia) also by the Dutch auction procedure.
A separate issue is the feasibility of including crowdfunding functions in the IDP «IRES». Based on the maintenance of high quality innovation process, the inclusion of such a function is impractical. Instead, it is possible to consider crowdfunding platforms separately as a tool for accumulating resources to form a feasibility study for innovative ideas. That is, the research organizations authorized by the IDP «IRES» can attract a resource for the preparation of feasibility studies through crowdfunding platforms.

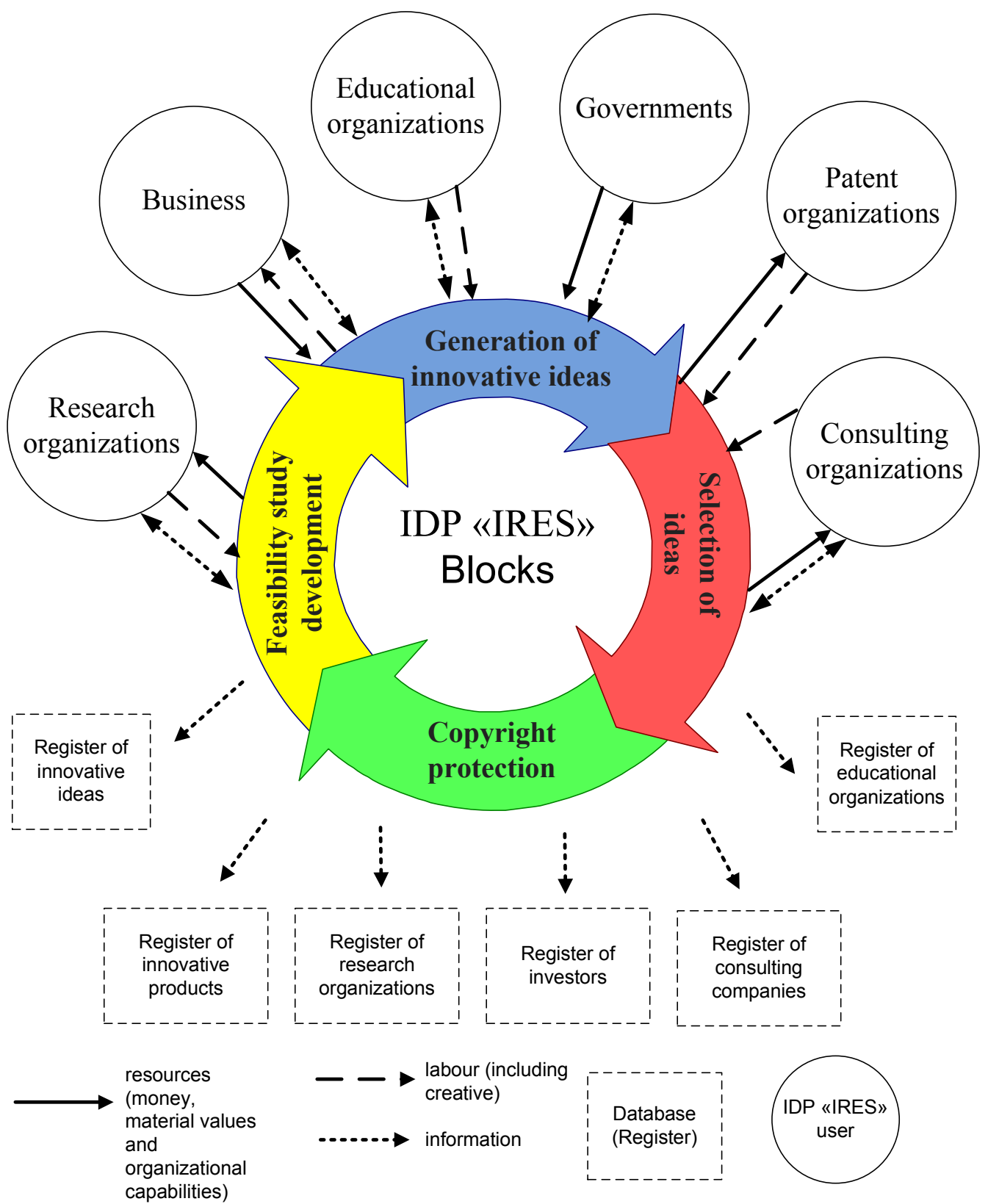

Figure. Conceptual model of the international digital platform of innovation, research, educational and spaces

Each of the participants (users) of the IDP «IRES» creates and receives a certain value from its activities (see Table).

In order to avoid monopolization within the innovation and scientific-educational space, it is desirable to have several international digital platforms operating on such principles.

As a result, the well-founded conceptual model of IDP «IRES» serves as a basis for a combination of technological and organizational tools on a modern digital 
O. Vyshnevskyi

Table

Value received and created from IDP «IRES» for groups of users

\begin{tabular}{|c|c|c|}
\hline $\begin{array}{l}\text { Group of users } \\
\text { IDP «IRES» }\end{array}$ & The value received from the IDP «IRES» & The value created for the IDP «IRES» \\
\hline Governments & $\begin{array}{l}\text { Promoting economic growth on an innova- } \\
\text { tive basis }\end{array}$ & Providing financial and other resources \\
\hline Business & $\begin{array}{l}\text { Gaining access to high-quality innovative } \\
\text { products that determine the possibility of ob- } \\
\text { taining innovative rents }\end{array}$ & Provision of financial resources and expertise \\
\hline $\begin{array}{l}\text { Research organi- } \\
\text { zations }\end{array}$ & $\begin{array}{l}\text { Financial and other material and organiza- } \\
\text { tional resources }\end{array}$ & Creating innovative ideas \\
\hline $\begin{array}{l}\text { Consulting organi- } \\
\text { zations }\end{array}$ & Financial resources & Expertise \\
\hline $\begin{array}{l}\text { Patent organiza- } \\
\text { tions }\end{array}$ & Financial resources & $\begin{array}{l}\text { Copyright protection, transformation of an in- } \\
\text { novative idea into a product }\end{array}$ \\
\hline $\begin{array}{l}\text { Educational or- } \\
\text { ganizations }\end{array}$ & $\begin{array}{l}\text { Opportunity to learn in the process of imple- } \\
\text { menting the innovation cycle }\end{array}$ & Organizational support of the platform \\
\hline
\end{tabular}

basis in order to form interstate and cross-border research, educational and innovation spaces.

\section{Conclusions}

1. In the current conditions for Ukraine, the greatest potential for economic growth is contained in the innovation and institutional spheres. In turn, mass innovation is impossible without developed scientific and educational spheres, which are its basis. This necessitates the activation and acceleration of innovative, scientific and educational activities in Ukraine, that requires strengthening international cooperation.

2. Among the main problems of the Ukrainian innovation, scientific and scientific space are their Weak integration into the European innovation space. This indicates the presence of untapped potential in this area.

3. A promising tool for integrating Ukrainian innovation, scientific and educational spaces into the corresponding European ones is the creation of an international digital platform that unites governments, business, research organizations, consulting organizations, patent organizations, educational organizations from Ukraine and EU countries.

4. The state of Ukraine has the opportunity to become the creator of such a platform, which can be done in two stages. At the first stage, initiate a platform to unite the Ukrainian innovation, educational and scientific space and one of the EU countries (for example, with Poland), and at the second, connect third countries from among the EU members.

\section{Literature}

1. Підоричева І. Ю. Україна у науково-технологічному та інноваційному просторах Свропейського Союзу: проблеми, позитивні зрушення та напрями інтеграції. Економічний вісник Донбасу. 2020. № 2 (60). C. 36-52. doi: 10.12958/1817-3772-2020-2(60)-36-52. 2. Ляшенко В.І., Підоричева І.Ю., Кучеров А.В., Тесновський П.В. Напрями інтеграції України до європейських науково-освітніх та інноваційних просторів в умовах Угоди про асоціацію з Свропейським Союзом. Економічний вісник Донбасу. 2018. № 3 (53). С. 147179. 3. Liashenko V., Pidorycheva I., Antoniuk V.
European Research Area: comparative analysis of institutional prerequisites and integration approaches for Ukraine. Journal of European Economy. July-September 2020. Vol. 19. № 3 (74). P. 456-481. doi: https://doi.org/10.35774/jee2020.03.456. 4. Іванов С. В., Антонюк В. П. Свропейський дослідницький простір та Україна: проблеми і перспективи інтеграції. Економічний вісник Донбасу. 2020. № 3(61). С. 166-176. doi: 10.12958/1817-3772-2020-3(61)-166-176. 5. Паркер Дж., Ван Альстин М., Чаудари. С. Революция платформ. Как сетевые рынки меняют экономику - и как заставить их работать на вас. Москва: Манн, Иванов и Фербер, 2017. 304 с. 6. Вишневський О. С. Вплив цифрових платформ на розвиток творчої праці. Вісник Одеського національного університету. Сер.: Економіка. 2020. Т. 25, Вип. 3(82). С. 8-12. doi: https: //doi.org/ 10.32782/ 2304-0920/3-82. 7. Evans P., Gawer A. The Rise of the Platform Enterprise. A Global Survey. The Center for Global Enterprise. 2016. 30 p. URL: https://www.thecge.net/app/uploads/2016/01/PDF-WEBPlatform-Survey_01_12.pdf. 8. Замбалаева Т. Б., Рыжкова М. В., Чиков М. В._Бизнес-схемы краудфандинговых платформ в обеспечении финансирования инновационного проекта. Экономика и управление инноваииями. 2019. № 2. С. 70-83. doi: 10.26730/2587-55742019-2-70-83. 9. Карпухин Д. Н. Академическая crowdsourcing-платформа, как форма привлечения инвестиций для малых инновационных предприятий. Проблемь экономики, финансов и управления производством. 2017. № 40. С. 75-79. 10. Васецкая Н. О. Анализ подходов к определению инновационного цикла с точки зрения получения макроэкономического результата. Вектор науки Тольяттинского государственного университета. Серия: Экономика и управление. 2020. № 3 (42). С. 18-23. doi: 10.18323/22215689-2020-3-18-23. 11. Вишневский А. С. Национальная цифровая платформа: перспективы создания в Украине. Вісник економічної науки Украӥни. 2020. № 1 (38). C. 219-223. doi: https://doi.org/10.37405/17297206.2020.1(38).219-223. 12. Іванов С. В., Вишневський О. С. Электронные платформы как инструмент модернизации экономики Украины. Вісник економічної науки Украӥни. 2017. № 1 (32). С. 47-53. 13. Ля- 
шенко В. І., Вишневський О. С. Цифрова модернізація економіки України як можливість проривного розвитку. Київ: Ін-т економіки пром-сті НАН України, 2018. $252 \mathrm{c}$

\section{References}

1. Pidorycheva, I. (2020). Ukraine in the scientifictechnological and innovative spaces of the European Union: problems, positive changes and directions of integration. Economic Herald of the Donbass, 2 (60), pp. 36-52. doi: 10.12958/1817-3772-2020-2(60)-36-52 [in Ukrainian].

2. Liashenko, V., Pidorycheva, I., Kucherov, A, Tesnovsky P. (2018). Directions of Ukraine's integration into the European scientific-educational and innovation spaces in the conditions of the Association Agreement with the European Union. Economic Herald of the Donbass. № 3 (53). P. 147-179. [in Ukrainian].

3. Liashenko, V., Pidorycheva, I., Antoniuk, V. (2020). European Research Area: comparative analysis of institutional prerequisites and integration approaches for Ukraine. Journal of European Economy, Vol. 19, No. 3 (74), pp. 456-481. doi: https://doi.org/10.35774/ jee2020.03.456.

4. Ivanov, S., Antoniuk, V. (2020). European Research Area and Ukraine: Problems and Prospects of Integration. Economic Herald of the Donbass, 3(61), pp. 166-176. doi: 10.12958/1817-3772-2020-3(61)-166176 [in Ukrainian].

5. Parker, G., Van Alsyne, M., Choudary, S. (2017). Platform Revolution: how Networked Markets are Transforming the Economy - and How to Make. Moscow, Mann, Ivanov and Ferber. 304 p. [in Russian].

6. Vyshnevskyi, O. (2020) The influence of digital platforms on the development of creative work. Bulletin of Odessa National University. Ser.: Economics, Vol. 25, No. 3(82), pp. 8-12. doi: https://doi.org/10.32782/23040920/3-82 [in Ukrainian].

7. Evans, P., Gawer, A. (2016). The Rise of the Platform Enterprise. A Global Survey. The Center for Global Enterprise. 30 p. Retrieved from https: //www.thecge.net/app/uploads/2016/01/PDF-WEB-Platfo rm-Survey_01_12.pdf.

8. Zambalaeva, T., Ryzhkova, M., Chikov, M. (2019). Business schemes of crowdfunding platforms in providing financing of an innovative project. Economics and innovation management, 2, pp. 70-83. doi: 10.26730/ 2587-5574-2019-2-70-83 [in Russian].

9. Karpukhin, D. (2017). Academic crowdsourcing platform as a form of investment attraction for small innovative enterprises. Problems of economics, finance and production management, 40, pp. 75-79 [in Russian].

10. Vasetskaya, N. (2020). Analysis of approaches to defining the innovation cycle from the point of view of obtaining a macroeconomic result. Vector science of Togliatti State University. Series: Economics and Management, 3 (42), pp. 18-23. doi: 10.18323/2221-56892020-3-18-23 [in Russian].

11. Vyshnevskyi, O. (2020). National digital platform: prospects for creation in Ukraine. Herald of the economic sciences of Ukraine, 1 (38), pp. 219-223. doi: https://doi.org/10.37405/1729-7206.2020.1(38).219-223 [in Russian].

12. Ivanov, S., Vyshnevskyi, O. (2017). Electronic platforms as a tool for modernizing the Ukrainian economy. Herald of the economic sciences of Ukraine, 1 (32), pp. 47-53. [in Russian].

13. Lyashenko, V., Vyshnevskyi, O. (2018). Digital modernization of the Ukrainian economy as an opportunity for breakthrough development. Kyiv, IIE of NAS of Ukraine [in Ukrainian].

Вишневський О. С. Міжнародна цифрова платформа як інструмент формування транскордонних науково-освітніх та інноваційних просторів

Мета дослідження - обгрунтувати дизайн міжнародної цифрової платформи як інструменту для формування транскордонного дослідного, освітнього та інноваційного просторів.

У чинних для України умовах найбільший потенціал економічного зростання міститься в інноваційній та інституційної сферах. У свою чергу, масові інновації неможливі без розвинених наукових і освітніх сфер, які $\epsilon$ їх основою. Це вимагає активізації і прискорення інноваційної, наукової та освітньої діяльності в Україні, що обумовлює необхідність зміцнення міжнародного співробітництва.

Серед основних проблем українського інноваційного, наукового i наукового простору виділяється їх слабка інтеграція в європейський інноваційний простір. Це вказує на наявність невикористаного потенціалу в цій галузі.

Перспективним інструментом інтеграції українських інноваційних, наукових і освітніх просторів у відповідні європейські є створення міжнародної цифрової платформи, що об'єднує уряди, бізнес, дослідницькі організації, консалтингові організації, патентні та освітні організації з України та країн СС.

У державі Україна $є$ можливість стати творцем такої платформи, що можна зробити в два етапи. На першому етапі ініціювати створення платформи для об'єднання українського інноваційного, освітнього і наукового простору та однієї з країн ЄС (наприклад, 3 Польщею), а на другому - підключати треті країни 3 числа членів СС.

Ключові слова: науково-освітній простір, інноваційний простір, міжнародна цифрова платформа, цифровізація, ЄС, Україна.

Vyshnevskyi O. International Digital Platform as a Tool for the Formation of Cross-Border Research, Educational and Innovation Spaces

The aim of the study is to substantiate design international digital platform as a tool for the formation of crossborder research, educational and innovation spaces.

In the current conditions for Ukraine, the greatest potential for economic growth is contained in the innovation and institutional spheres. In turn, mass innovation is impossible without developed scientific and educational spheres, which are its basis. This necessitates the activation and acceleration of innovative, scientific and educational activities in Ukraine, that requires strengthening international cooperation. 
Among the main problems of the Ukrainian innovation, scientific and scientific space are their Weak integration into the European innovation space. This indicates the presence of untapped potential in this area.

A promising tool for integrating Ukrainian innovation, scientific and educational spaces into the corresponding European ones is the creation of a international digital platform that unites governments, business, research organizations, consulting organizations, patent organizations, educational organizations from Ukraine and EU countries.

The state of Ukraine has the opportunity to become the creator of such a platform, which can be done in two stages. At the first stage, initiate a platform to unite the Ukrainian innovation, educational and scientific space and one of the EU countries (for example, with Poland), and at the second, connect third countries from among the EU members.

Keywords: research space, educational space, innovation space, international digital platform, digitalization, EU, Ukraine.

Вишневский А. С. Международная цифровая платформа как инструмент формирования трансграничных научно-образовательных и инновационных пространств

Цель исследования - обосновать дизайн международной цифровой платформы как инструмента для формирования трансграничного исследовательского, образовательного и инновационного пространств.

В нынешних для Украины условиях наибольший потенциал экономического роста содержится в инно- вационной и институциональной сферах. В свою очередь, массовые инновации невозможны без развитых научных и образовательных сфер, которые являются их основой. Это требует активизации и ускорения инновационной, научной и образовательной деятельности в Украине, что обусловливает необходимость укрепления международного сотрудничества.

Среди основных проблем украинского инновационного, научного и научного пространства выделяется их слабая интеграция в европейское инновационное пространство. Это указывает на наличие неиспользованного потенциала в этой области.

Перспективным инструментом интеграции украинских инновационных, научных и образовательных пространств в соответствующие европейские является создание международной цифровой платформы, объединяющей правительства, бизнес, исследовательские организации, консалтинговые организации, патентные организации и образовательные организации из Украины и стран ЕС.

У государства Украина есть возможность стать создателем такой платформы, что можно сделать в два этапа. На первом этапе инициировать платформу для объединения украинского инновационного, образовательного и научного пространства и одной из стран ЕС (например, с Польшей), а на втором - подключать третьи страны из числа членов ЕС.

Ключевые слова: научно-образовательное пространство, инновационное пространство, международная цифровая платформа, цифровизация, ЕС, Украина.

Received by the editors: 08.12 .2020 and final form 29.12.2020 